\title{
A study of materno-fetal outcomes in cases of jaundice during pregnancy
}

\author{
Hrishikesh Joshi, Amrita Kishor Jeswani, Sangeeta Sheetal Desai
}

Corresponding author: Dr. Sangeeta Sheetal Desai, Associate Professor in Obstetrics \& Gynecology, D.Y. Patil Medical College, D.Y. Patil Education Society (Deemed University), Kolhapur, 416 006, Maharashtra, India; Email : klpskdesai@gmail.com

Distributed under Attribution-Non Commercial - Share Alike 4.0 International (CC BY-NC-SA 4.0)

\begin{abstract}
Objectives: This study aimed to determine clinico-etiological, biochemical factors and materno-fetal outcome in women with jaundice during pregnancy and to study its correlation with jaundice in pregnancy. Methodology: A total of 25 pregnant patients with abnormal liver functioning were included in this observational study. Demographics and the detailed clinical history were recorded. The detailed laboratory investigation was carried out to study the complications concerning biochemical parameter. Results: HELLP syndrome was the most common aetiology (40\%). Decreased levels of hemoglobin observed in $76 \%$, increased total leukocyte count observed in $28 \%$ and low platelet count observed in 32\% respectively. Among mothers, most common adverse outcome was requirement of emergency lower segment caesarean section (LSCS) (44\%). Raised serum total bilirubin level, direct bilirubin level and thrombocytopenia were significantly associated with adverse fetal outcomes $(\mathrm{P}=0.046, \mathrm{P}=0.024, \mathrm{P}=0.027$ respectively). Maternal outcomes were significantly associated with raised direct bilirubin, raised serum glutamic pyruvic transaminase (SGPT), raised alkaline phosphatase and thrombocytopenia $(\mathrm{P}=0.034, \mathrm{P}=0.010, \mathrm{P}=0.023$, $\mathrm{P}=0.001$ respectively). Conclusion: Hepatic dysfunction during pregnancy is associated with adverse events for both the mother and the fetus.
\end{abstract}

Keywords: Alanine transaminase, alkaline phosphatase, bilirubin, liver diseases, low birth weight, thrombocytopenia.

Liver diseases during pregnancy presents a distinctive clinical challenge for gynaecologist and herpatologist as they are poorly studied and may lead to materno-fetal complications. ${ }^{1}$ The prevalence of liver dysfunction during pregnancies ranges between 3-10\%. ${ }^{2}$ Jaundice, also referred as hyperbilirubinemia, is presented by accumulation of bile pigments in the skin that results in yellowing mucous membranes and the skin. ${ }^{3,4}$ Jaundice in pregnancy may lead to adverse materno-fetal outcomes including perinatal and maternal mortality which accounts for around $60 \%$ and $14 \%$ respectively. ${ }^{5}$ However, it is caused by a number of causes, some related and some coincidental including abnormal liver functioning distinctive to pregnancy, pre-hepatic causes, hepatic causes and post-hepatic causes of jaundice.
Abnormal liver functioning distinctive to pregnancy are HELLP syndrome, pre-eclampsia, acute fatty liver, hyperemesis gravidarum and intrahepatic cholestasis of pregnancy. Pre-hepatic causes including hepatic pathologies (viral hepatitis), haemolytic anaemia, drug-induced hepatitis, Wilson's disease and Budd-Chiari syndrome. Post-hepatic causes include CBD obstructions, pancreatitis, choledochal cyst and gall stones.

Although jaundice in pregnancy is relatively rare, it may lead to serious materno-fetal complications. This study aimed to determine clinico-etiological, biochemical factors and materno-fetal outcome in women with jaundice during pregnancy and to study its correlation with jaundice in pregnancy.

Received: $5^{\text {th }}$ February 2021, Peer review completed: $10^{\text {th }}$ April 2021, Accepted: $1^{\text {st }}$ May 2021.

Joshi H, Jeswani AK, Desai SS. A study of materno-fetal outcomes in cases of jaundice during pregnancy. The New Indian Journal of OBGYN. 2022; 8(2): 209 - 13. 
The New Indian Journal of OBGYN. 2021 (January-June);8(2)

\section{Materials and methods}

Post receiving institutional ethical committee clearance, the observational study was conducted in department of obstetrics and gynaecology of a tertiary care hospital, in western Maharashtra from July 2018 to December 2019. The sample size was calculated in $\mathrm{R}$ studio software using standard formula [pwr. Chisq. test (effect size $=0.60, \mathrm{df}=1$, power $=0.80$, sig. level $=0.05$ ) $]$ at $95 \%$ significance level, power being $80 \%$ and the minimum sample size was found to be 21 . A total of 25 patients with abnormal liver functions were included. All pregnant patients with abnormal liver function tests were included in this study. Patients with normal liver functioning were excluded. Written informed consent was obtained from all the patients prior to the study. Demographic data and a detailed clinical history were collected including age, obstetrical profile, gravida, aetiology. The detailed laboratory investigation was carried out to study the complications concerning biochemical parameter. Maternal and fetal outcomes were also recorded.

The data collected were organized in MS-Excel (2016). Association between the biochemical factors and the maternal and fetal outcomes were analysed by chi square test in Statistical Package for the Social Sciences (SPSS) software. $\mathrm{P}$ value $<0.05$ was considered as statistically significant.

\section{Results and observations}

Mean age of the patients was $25.2 \pm 3.78$ years. Of the 25 patients, 11 patients (44\%) belonged to the age group 21- 25 years. Distribution of the patients concerning their age is given in table 1.

Table 1: Age group

\begin{tabular}{lll}
\hline Age groups & No. of patients $(\mathbf{n}=\mathbf{2 5})$ & Percentage $(\%)$ \\
\hline$<20$ years & 3 & 12 \\
21 to 25 years & 11 & 44 \\
26 to 30 years & 9 & 36 \\
$>31$ Years & 2 & 8 \\
\hline
\end{tabular}

Figure 1 represents that HELLP syndrome was the most common etiology (40\%). Whereas, thrombotic thrombocytopenic purpura (TTP) (4\%), leptospirosis (4\%) and PRESS syndrome (4\%) were least common.

High number of patients had low level of $\mathrm{Hb}(76 \%)$, total leukocyte count between 7000-11000 cells/ $\mu \mathrm{L}(60 \%)$, platelets $>150000$ cells $/ \mu \mathrm{L}(40 \%)$, total bilirubin $<2 \mathrm{mg} / \mathrm{dL}$ $(60 \%)$, direct bilirubin $>0.2 \mathrm{mg} / \mathrm{dL}(80 \%)$, serum glutamic oxaloacetic transaminase $(\mathrm{SGOT})>70 \mathrm{U} / \mathrm{Lit}(76 \%)$, serum glutamic pyruvic transaminase $(\mathrm{SGPT})>70 \mathrm{U} / \mathrm{Lit}(76 \%)$, alkaline phosphatase $>180$ IU/Lit $\quad(68 \%)$, lactase dehydrogenase $>600 \mathrm{U} / \mathrm{Lit}(84 \%$ ), albumin $>2.5 \mathrm{gm} / \mathrm{dL}$ $(60 \%)$, total protein $>8.5 \mathrm{gm} / \mathrm{dL}(52 \%)$, urea $>6.8 \mathrm{mg} / \mathrm{dL}$
$(60 \%)$ and creatinine $>1.42 \mathrm{mg} / \mathrm{dL}(60 \%)$, as shown in table 2 .

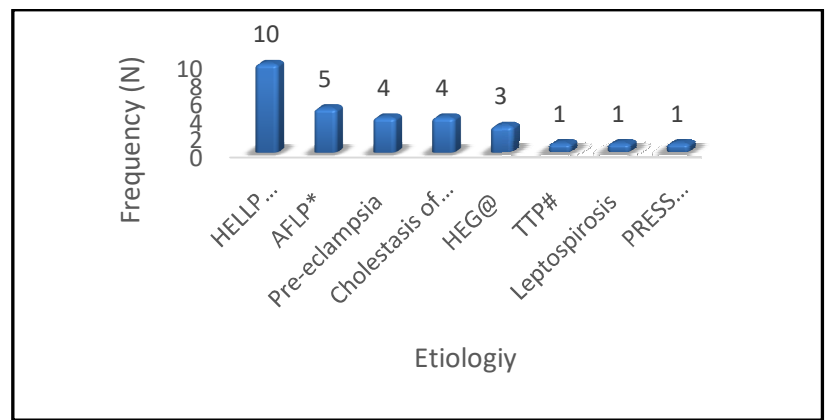

(* Acute fatty liver of pregnancy; @ Hyper-emesis gravidarum; \# Thrombotic thrombocytopenic purpura)

Figure 1: Etiological factors

\begin{tabular}{|c|c|c|c|}
\hline $\begin{array}{l}\text { Laboratory } \\
\text { values }\end{array}$ & Category & $\begin{array}{c}\text { No. of } \\
\text { patients } \\
(n=25)\end{array}$ & $\begin{array}{c}\text { Percentage } \\
(\%)\end{array}$ \\
\hline \multirow{2}{*}{$\mathrm{Hb}(\mathrm{gm} \%)$} & $<7$ & 19 & 76 \\
\hline & $>7$ & 06 & 24 \\
\hline \multirow{3}{*}{$\begin{array}{l}\text { Total leukocyte Count } \\
\text { (cells } / \mu \mathrm{L})\end{array}$} & $<7000$ & 03 & 12 \\
\hline & $7000-11000$ & 15 & 60 \\
\hline & $>11000$ & 07 & 28 \\
\hline \multirow{3}{*}{$\begin{array}{l}\text { Platelets } \\
(\text { cells } / \mu \mathrm{L})\end{array}$} & $<50000$ & 08 & 32 \\
\hline & $51000-150000$ & 07 & 28 \\
\hline & $>150000$ & 10 & 40 \\
\hline \multirow{2}{*}{ Total bilirubin (mg/dL) } & $<2$ & 15 & 60 \\
\hline & $>2$ & 10 & 40 \\
\hline \multirow{2}{*}{$\begin{array}{l}\text { Direct bilirubin } \\
(\mathrm{mg} / \mathrm{dL})\end{array}$} & $<0.2$ & 05 & 20 \\
\hline & $>0.2$ & 20 & 80 \\
\hline \multirow[b]{2}{*}{ SGOT (U/Lit) } & $<70$ & 06 & 24 \\
\hline & $>70$ & 19 & 76 \\
\hline \multirow{2}{*}{ SGPT (U/Lit) } & $<70$ & 06 & 24 \\
\hline & $>70$ & 19 & 76 \\
\hline \multirow{2}{*}{$\begin{array}{l}\text { Alkaline phosphatase } \\
\text { (IU/Lit) }\end{array}$} & $<180$ & 08 & 32 \\
\hline & $>180$ & 17 & 68 \\
\hline \multirow{2}{*}{$\begin{array}{l}\text { Lactase dehydrogenase } \\
\text { (U/Lit) }\end{array}$} & $<600$ & 04 & 16 \\
\hline & $>600$ & 21 & 84 \\
\hline \multirow{2}{*}{ Albumin (gm/dL) } & $<2.5$ & 10 & 40 \\
\hline & $>2.5$ & 15 & 60 \\
\hline \multirow{2}{*}{ Total protein $(\mathrm{gm} / \mathrm{dL})$} & $<8.5$ & 12 & 48 \\
\hline & $>8.5$ & 13 & 52 \\
\hline \multirow{2}{*}{ Urea (mg/dL) } & $<6.8$ & 10 & 40 \\
\hline & $>6.8$ & 15 & 60 \\
\hline \multirow{2}{*}{ Creatinine (mg/dL) } & $<1.4$ & 10 & 40 \\
\hline & $>1.4$ & 15 & 60 \\
\hline
\end{tabular}

$\mathrm{Hb}$ - Haemoglobin, SGOT - Serum glutamic oxaloacetic transaminase, SGPT - Serum glutamic pyruvic transaminase

Among 25 cases showed, adverse maternal and fetal outcomes were observed in 17 and 19 cases, respectively. Low birth weight was observed as commonest adverse fetal outcomes in $56 \%$ of cases. Among mothers, most common adverse outcome was requirement of emergency lower segment caesarean section (LSCS) (44\%) (table 3). 
Table 3: Maternal and foetal outcomes

\begin{tabular}{ccc}
\hline Neonatal Outcomes & No. of patients & Percentage \\
\hline Low birth weight & 14 & $56 \%$ \\
IUGR & 11 & $44 \%$ \\
Preterm & 10 & $40 \%$ \\
Neonatal death & 03 & $12 \%$ \\
\hline Maternal outcomes & No. of patients & Percentage \\
LSCS & 11 & $44 \%$ \\
ICU admission & 10 & $40 \%$ \\
Blood transfusion & 09 & $36 \%$ \\
Maternal mortality & 01 & $04 \%$ \\
\hline IUGR - Intrauterine growth retardation, LSCS - Lower segment \\
caesarean section, ICU - Intensive care unit.
\end{tabular}

Raised serum total bilirubin level, direct bilirubin level and thrombocytopenia were significantly associated with adverse fetal outcomes. Maternal outcomes were significantly associated with raised direct bilirubin, raised SGPT, raised alkaline phosphatase and thrombocytopenia (table 4). involve abnormalities in placental vasculature and defects in maternal vascular endothelial cells, which results in poor perfusion. ${ }^{7}$

In developing countries, anaemia is a public health problem especially during pregnancy. ${ }^{11}$ World Health Organization (WHO) has defined anaemia in pregnancy as the haemoglobin concentration of less than $11 \mathrm{~g} / \mathrm{dl} .^{12}$ Laboratory investigation in the present study revealed that $76 \%$ of the patients had haemoglobin $<7 \mathrm{gm} / \mathrm{dl}$ and $28 \%$ had raised total leukocytic count. Platelets were found to be $<50000$ cells $/ \mu \mathrm{L}$ in $32 \%$. These laboratory findings are comparable with the study conducted by Suresha et al where, anaemia (37\%), thrombocytopenia (31\%) and coagulopathy (26\%) were observed. ${ }^{2}$

Alteration in blood count is a common phenomenon in

Table 4: Association between abnormal lab parameters and adverse fetal and maternal outcomes

\begin{tabular}{|c|c|c|c|c|}
\hline $\begin{array}{l}\text { Laboratory } \\
\text { parameters }\end{array}$ & $\begin{array}{l}\text { Adverse fetal outcome } \\
(n=17)\end{array}$ & $\begin{array}{l}P \\
\text { value }\end{array}$ & $\begin{array}{l}\text { Adverse maternal outcome } \\
(\mathrm{n}=19)\end{array}$ & $\begin{array}{l}P \\
\text { value }\end{array}$ \\
\hline Total bilirubin $>2 \mathrm{mg} / \mathrm{dL}$ & $10(58.82 \%)$ & $0.046^{*}$ & $10(52.63 \%)$ & 0.33 \\
\hline Direct bilirubin $>0.3 \mathrm{mg} / \mathrm{dL}$ & $17(100 \%)$ & $0.024 *$ & $19(100 \%)$ & $0.034 *$ \\
\hline SGOT $>70 \mathrm{U} /$ Lit & $11(64.71 \%)$ & 0.18 & $13(68.42 \%)$ & $0.010^{*}$ \\
\hline SGPT>70U/Lit & $10(58.82 \%)$ & 0.37 & $10(52.63 \%)$ & 0.62 \\
\hline Alkaline phosphatase $>180 \mathrm{IU} /$ Lit & $06(35.29 \%)$ & 0.57 & $08(42.11 \%)$ & $0.023^{*}$ \\
\hline $\mathrm{LDH}>600 \mathrm{U} / \mathrm{Lit}$ & $08(47.06 \%)$ & 0.65 & $07(36.84 \%)$ & 0.63 \\
\hline Albumin $<2.5 \mathrm{gm} / \mathrm{dL}$ & $04(23.53 \%)$ & 0.62 & $04(21.05 \%)$ & 0.95 \\
\hline Total protein $<8.5 \mathrm{gm} / \mathrm{dL}$ & $17(100 \%)$ & 1.0 & $19(100 \%)$ & 1.0 \\
\hline Urea $>6.8 \mathrm{mg} / \mathrm{dL}$ & $16(94.12 \%)$ & 0.51 & $18(94.74 \%)$ & 0.38 \\
\hline Creatinine $>1.4 \mathrm{mg} / \mathrm{dL}$ & $2(11.76 \%)$ & 0.90 & $02(10.53 \%)$ & 0.52 \\
\hline Hemoglobin $<7 \mathrm{gm} \%$ & $5(29.41 \%)$ & $0.05^{*}$ & $05(26.32 \%)$ & $0.05^{*}$ \\
\hline Total leukocyte count $>11000$ cells $/ \mu \mathrm{L}$ & $8(47.06 \%)$ & 0.84 & $09(47.37 \%)$ & 0.63 \\
\hline Platelet count $<50000$ cells $/ \mu \mathrm{L}$ & $3(17.65 \%)$ & $0.027 *$ & $02(10.53 \%)$ & $0.001^{*}$ \\
\hline
\end{tabular}

*Statistically significant, LDH - Lactate dehydrogenase, SGOT - Serum glutamic oxaloacetic transaminase, SGPT - Serum glutamic pyruvic transaminase

\section{Discussion}

HELLP syndrome is defined as increased blood pressure with proteinuria or end-organ dysfunction in absence of proteinuria seen post 20 weeks of gestation. ${ }^{7}$ However, in the present study, HELLP syndrome was the most common syndrome seen (44\%) followed by acute fatty liver of pregnancy (AFLP) $(32 \%)$, preeclampsia $(28 \%)$, cholestasis of pregnancy (28\%) and hyperemesis gravidarum (HEG)(12\%). Similarly, in study by Reddy et al, HELLP syndrome was most common and was observed in $33.3 \%$ patients, followed by acute fatty liver of pregnancy in $22.2 \%$ and intrahepatic cholestasis of pregnancy in $11.1 \%$ patients. ${ }^{8}$ Contradictorily, in a study conducted by Suresha et al and Allen et al, HELLP syndrome was the second common aetiology after eclampsia and preeclampsia, respectively. ${ }^{2,9}$ Satia et al, reported viral hepatitis $(62 \%)$ as the commonest aetiology followed by cholestasis of pregnancy $(24 \%) .{ }^{10}$ The pathogenesis of HELLP is still not clear but is believed to pregnancy. ${ }^{13,}{ }^{14}$ However, in this study, it can also be attributed to the presence of HELLP syndrome, which is associated with vascular endothelial abnormalities. ${ }^{15}$

Liver dysfunction was quite evident in high number of patients due to increased level of bilirubin. SGOT, SGPT and level of bilirubin were high in $76 \%, 76 \%$ and $40 \%$ of cases respectively. However, in a similar study, Ronceglia et al reported moderately increased bilirubin level of 1-10 mg\% and hypoglycaemia. ${ }^{16}$ Shinde et al, also reported elevated bilirubin level in the pregnant patients with jaundice compared to non-pregnant patients. ${ }^{17}$ In their study, serum bilirubin levels between $11-15 \mathrm{mg} / \mathrm{dl}$ and between 16 and $25 \mathrm{mg} / \mathrm{dl}$ were recorded in $38.4 \%$ and $19.2 \%$ of pregnant patients, respectively. However, among non- pregnant patients, $36.5 \%$ had serum bilirubin between 6 and $10 \mathrm{mg} / \mathrm{dl}^{17}$

Most common adverse neonatal outcome was low birth weight $(56 \%)$ followed by intrauterine growth retardation (IUGR) (44\%). Forty percent of the neonates were preterm, 
and rate of neonatal death was found to be $12 \%$. In the present study percentage of fetal deaths due to jaundice amongst total perinatal deaths was $12 \%$. Parveen et al also reported low birth weight as the commonest adverse fetal outcomes. ${ }^{18}$ This can be attributed to the low levels of haemoglobin among mothers, as it limits the oxygen supply to the fetus which results in restriction of intrauterine growth and low birth weight. ${ }^{19}$ Bora et al reported the significant association between fetal birth weight and anaemia (mild and severe). ${ }^{20}$ Interestingly, very high perinatal mortality rate of $45.45 \%$ was reported by Singh et al. ${ }^{21}$

Among mothers, most common adverse outcome was requirement of emergency LSCS (44\%), need of ICU admission (40\%) and blood transfusion (36\%). In the present study one maternal death (4\%) was observed. Fascinatingly, D'Souza et al, reported disseminated intravascular coagulation (DIC) as the commonest adverse maternal outcomes. ${ }^{22}$ High number of maternal deaths were reported by Kamalajayaram et al and Singh et al as 33.3\% and $10 \%$ respectively. ${ }^{23,21}$

HELLP syndrome is associated with weight gain and oedema in $60 \%$, maternal mortality of $20 \%$, and neonatal mortality rate of $31 \% .^{23}$ In acute fatty liver during pregnancy, maternal mortality is $18 \%$ while preterm labour is increased, and the perinatal mortality is $23 \%$. $^{23}$

Raised serum total bilirubin level $(\mathrm{P}=0.046)$, direct bilirubin level $(\mathrm{P}=0.024)$, thrombocytopenia $(\mathrm{P}=0.027)$, low haemoglobin level $(\mathrm{P}=0.05)$ was significantly associated with adverse fetal outcomes. Although median levels of maternal haemoglobin were normal overall, a significantly lower level was seen in females who had adverse events. Various studies have described the relationship between maternal anaemia and adverse fetal outcome. ${ }^{20,} 24$ Raised direct bilirubin $(\mathrm{P}=0.034)$, raised SGOT $(\mathrm{P}=0.010)$, raised alkaline phosphatase $(\mathrm{P}=0.023)$, low haemoglobin level $(\mathrm{P}=0.05)$ and thrombocytopenia $(\mathrm{P}=0.001)$ were found to be significantly associated with adverse maternal outcome among the patients. Maternal deaths were directly proportional to the level of the serum bilirubin. Trivedi et al also reported similar findings. ${ }^{25}$ Trivedi et al also stated that the initial bilirubin level at admission, $>10$ is associated with poor maternal outcome and high maternal mortality. ${ }^{25}$ Therefore, these laboratory parameters could be considered as a predictor of adverse maternal and fetal outcomes.

The studies on this topic are rather limited in recent years; therefore, this study contributes widely to understanding the effect of jaundice during pregnancy.
However, comparative study between pregnant women with and without jaundice would contribute to derive conclusive results.

\section{Conclusion}

In pregnancies, patients with hepatic abnormalities form a special subset. The symptoms are usually non-specific. Overall, hepatic abnormalities during pregnancies consequently have the adverse effect on both maternal and neonatal outcomes. Maternal anaemia, thrombocytopenia, coagulopathy, and hyperbilirubinemia are also evident. Early diagnosis of these patients is crucial and may reduce the adverse outcomes of both mother and the new-born.

\section{Conflict of interest: None. Disclaimer: Nil.}

\section{References}

1. Mikolasevic I, Filipec-Kanizaj T, Jakopcic I, et al. Liver disease during pregnancy: a challenging clinical issue. Med Sci Mon Int Med J Exp Clin Res. 2018; 24: 4080.

2. Suresh I, Vijaykumar TR, Nandeesh HP. Predictors of fetal and maternal outcome in the crucible of hepatic dysfunction during pregnancy. Gastroentero Res. 2017;10(1): 21.

3. International Classification of Diseases, Tenth Revision, Clinical Modification (ICD-10-CM). [internet] Available from: www.cdc.gov/nchs/icd/icd10 cm.htm. Assessed 28 Sept 2017.

4. Cunningham G, Leveno KJ, Bloom SL, Hauth JC, Rouse DW, Spong CY. Hepatic, gallbladder, and pancreatic disorders. Williams Obstetrics. 3rd ed. McGraw Hill: New York; 2010.

5. Choudhary N, Sen S, Varalakshmi K. A prospective study on pregnancy complicated with jaundice with special emphasis on fetomaternal outcome. Int J Reprod Contracept Obstet Gynecol. 2017; 6(11): $\quad$ 5081-88.

6. Changede P, Chavan N, Raj N, Gupta P. An observational study to evaluate the maternal and Foetal outcomes in pregnancies complicated with jaundice. J Obstet Gynecol India. 2019; 69(1): 31-6.

7. Sharma AV, John S. Liver Disease in Pregnancy. In Stat Pearls [Internet] 2019 Jul 30. Stat Pearls Publishing. Available from: https://www.ncbi.nlm.nih. gov/books/ NBK482201/

8. Reddy MG, Prabhakar GC, Sree V. Maternal and fetal outcome in jaundice complicating pregnancy. J NTR Uni Health Sci. 2014; 3: 231-33.

9. Allen AM, Kim WR, Larson JJ, et al. The epidemiology of liver diseases unique to pregnancy in a US 
The New Indian Journal of OBGYN. 2021 (January-June);8(2)

community: a population-based study. Clin Gastroenterol Hepatol. 2016;14: 287-94.

10. Satia MN, Jandhyala MA. Study of feto maternal outcomes in cases of jaundice at a tertiary care center. Int J Rep Contracept Obst Gynecol 2016; 5: 2352 - 57.

11. Black RE, Victora CG, Walker SP, et al. Maternal and child undernutrition and overweight in low-income and middle-income countries. 2013; 382: 427 - 51.

12. World Health Organization. The World Health Report 2001: Mental health: new understanding, new hope. Geneva: World Health Organization; 2001.

13. Stephen G, Mgongo M, Hussein Hashim T, Katanga J, Stray-Pedersen B, Msuya SE. Anaemia in pregnancy: Prevalence, risk factors, and adverse perinatal outcomes in Northern Tanzania. Anemia. 2018; Article ID 1846280; 1-9.

14. Bakrim S, Motiaa Y, Ouarour A, Masrar A. Hematological parameters of the blood count in a healthy population of pregnant women in the Northwest of Morocco (Tetouan-M'diq-Fnideq provinces). Pan Afr Med J. 2018; 29:1-2.

15. Lata I. Hepatobiliary diseases during pregnancy and their management: An update. Int J Crit Illn Inj Sci. 2013; 3:175-82.

16. Ronceglia N, Trio D. Roffi L, et al. Intrahepatic cholestasis in pregnancy: incidence, clinical course, complications. Ann Obst Gynecol Med Perinat. 1991; 112:146-51.

17. Shinde NR, Patil TB, Deshpande AS, Gulhane RV, Patil MB, Bansod YV. Clinical profile, maternal and fetal outcomes of acute hepatitis E in pregnancy. Ann Med Health Sci Res. 2014; 4:133-39.

18. Parveen T, Begum F, Akhter N. Feto-Maternal Outcome of Jaundice in Pregnancy in a Tertiary Care Hospital. Mymensingh Med J. 2015; 24: 528-36.

19. Stangret A, Wnuk A, Szewczyk G, Pyzlak M, Szukiewicz D. Maternal hemoglobin concentration and hematocrit values may affect fetus development by influencing placental angiogenesis. J Matern Fetal Neonatal Med. 2017; 30:199-204.

20. Bora R, Sable C, Wolfson J, Boro K, Rao R. Prevalence of anemia in pregnant women and its effect on neonatal outcomes in Northeast India. J Matern Fetal Neonatal Med. 2014; 27: 887-91.

21. Singh S, Chauhan R, Patel RS. Jaundice in pregnancy. J Obst Gynecol India. 1991; 41:187-89.

22. D'Souza AS, Gupta G, Sandeep SG, Katumalla FS, Goyal S. Maternal and fetal outcome in liver diseases of pregnancy: a tertiary hospital experience. International Journal of Scientific and Research Publications. 2015; 5:1-4.

23. Kamalajayaram V, Rama Devi A. A study of maternal mortality in jaundice. J Obst Gynecol India. 1988; 38: 439-41.

24. Manisha N, Manoj KC, Saswati SC, Swapna DK, Umesh CS, Premila W, Marian K. Association between maternal anaemia and pregnancy outcomes: A cohort study in Assam, India. BMJ Global Health. 2016;1: e000026.

25. Trivedi SS, Goyal U, Gupta U. A study of maternal mortality due to viral hepatitis. J Obstet Gynecol India. 2003; 53: 551-53.

\footnotetext{
Hrishikesh Joshi ${ }^{1}$, Amrita Kishor Jeswani ${ }^{2}$, Sangeeta Sheetal Desai ${ }^{3}$

${ }^{1}$ Assistant Professor in Obstetrics \& Gynecology, D.Y. Patil Medical College, D.Y. Patil Education Society (Deemed University), Kolhapur, 416 006, Maharashtra, India; ${ }^{2}$ Junior Resident, Obstetrics \& Gynecology, D.Y. Patil Medical College, D.Y. Patil Education Society (Deemed University), Kolhapur, 416 006, Maharashtra, India; ${ }^{3}$ Associate Professor in Obstetrics \& Gynecology, D.Y. Patil Medical College, D.Y. Patil Education Society (Deemed University), Kolhapur, 416 006, Maharashtra, India.
} 